\title{
Chapter 13 \\ Social Innovation in Higher Education from a Disability Studies Perspective
}

\author{
Csilla Cserti-Szauer, Anikó Sándor, Vanda Katona, and György Könczei
}

\begin{abstract}
Due to the traditionally highly hierarchical nature of science, close connection with praxis is not always smooth. Participatory approaches can significantly support the balancing of power and the connection of academic theory with practice. In (Critical) Disability Studies, it is particularly important that user needs are met through co-productive design, and implementation. In this chapter after providing the theoretical foundation of (Critical) Disability Studies, our experiences are summarized in research, teaching, and service development, highlighting the strengths and challenges of the participatory approach to enrich the social innovation ecosystem. Finally, the chapter points out the adaptation and many possibilities of the participatory method that might create inclusive networks and communities in higher education.
\end{abstract}

Keywords Persons with disability $\cdot$ Social inclusion $\cdot$ Social innovation · Disability Studies $\cdot$ Participatory method

\section{The Key Points of the Chapter Are the Following}

- To demonstrate the role of higher education in generating social innovations that respond to the needs of persons with disability.

\footnotetext{
C. Cserti-Szauer $(\bowtie)$

Eötvös Loránd University, Bárczi Gusztáv Faculty of Special Needs Education, Budapest, Hungary

Eötvös Loránd University, Faculty of Education and Psychology, Doctoral School of Education, Budapest, Hungary

e-mail: szauer.csilla@barczi.elte.hu
}
A. Sándor · V. Katona · G. Könczei
Eötvös Loránd University, Bárczi Gusztáv Faculty of Special Needs Education, Budapest,
Hungary
e-mail: sandor.aniko@barczi.elte.hu; katona.vanda@barczi.elte.hu;
konczei.gyorgy@barczi.elte.hu
C. Păunescu et al. (eds.), Social Innovation in Higher Education, Innovation,
Technology, and Knowledge Management,
https://doi.org/10.1007/978-3-030-84044-0_13 
- To understand the importance of connecting the participatory approach to (Critical) Disability Studies.

- To present co-productive practical solutions in (Critical) Disability Studies.

- To support the learning of theoretical and practical experiences in the field of participatory research and teaching.

- To show an example of participatory innovation through inclusive service development.

- To enrich the social innovation ecosystem with the possibilities of increasing the frequency that the participatory approach is used in (Critical) Disability Studies.

\section{Introduction}

Many of the world's 1 billion people with disability face discrimination and oppression every day. They lack access to mainstream health, education, housing and labour market services. They are more likely than nondisabled people to live in poverty. They cannot exercise their full range of rights and be active members of their communities. (WHO \& World Bank, 2011; Könczei \& Sándor, 2019) As stakeholders in higher education, we have to take steps to change this unfair situation.

Our starting point and primary scientific discipline is (Critical) Disability Studies, therefore, an inter- and transdisciplinary system of knowledge and action dating back approximately half a century. As the theoretical basis of participatory research and higher education, (Critical) Disability Studies is defined as a critical social scientific discipline that never forgets about reflecting onto the hidden and oppressive power that exists in the society. It can be also characterized by mutual and deep respect between co-working individuals of the educating, researching and developing teams. Participatory research, education and innovation remain ever vigilant of their own voice of persons with disability (Könczei, 2018).

(Critical) Disability Studies also understands the complexity of disability, reveals the causes of marginalisation, maps the social and cultural causes of exclusion, and focuses on power.

Researchers dedicated to (Critical) Disability Studies are characterized by concentrated and deliberate theoretical and empirical self-monitoring, careful and on-going self-reflection and the need to form and continuously rewrite their findings, theorems and canons. In addition to this keen attention, a commitment to scientific humility is another strength of the discipline.

(Critical) Disability Studies also ventures into barely researched areas, putting the life experience and narratives of persons with disability in focus. Researchers are interested in exploring the systems of power (macro- and micro-power) and understanding their mechanisms of operation. It draws attention to the tangled threads of social interdependence, the so-called multidimensional interpretations of 'otherness', the significance of diversity and its value-creating power. For instance, linking issues of gender, sexuality, race and ethnicity to disability, or critically analysing public services such as inclusive and special school systems and proposing changes to school culture. 
The activities of researchers dedicated to (Critical) Disability Studies are not satisfied with exploring, analysing and describing and publishing the results. They want to make an impact. The aim is to develop a conceptual system that allows for the analysis of social processes, power dynamics and cultural meanings, to achieve progressive social change: inclusivity, equal opportunities, emancipation and accessibility. At the individual level, the goal is self-determination, self-advocacy, empowerment, and well-being.

Close attention to the voices of the people involved in our activities is achieved in a number of ways, e.g., by everyday personal relationships and conversations and by researching, teaching and developing together with members of the affected community. In (Critical) Disability Studies, persons with disability are subjects, contributors and partners as opposed to objects (Walmsley, 2001; Goodley, 2017; Könczei, 2018).

Based on the theoretical foundations of (Critical) Disability Studies the chapter presents developments in higher education that strengthen the social participation of people with disability through participatory research, education and innovation. Section 2 presents the theoretical framework of a common interface between (Critical) Disability Studies and Innovation Management. Section 3 focuses on theoretical and practical examples of this interdisciplinary approach in research, education and innovation. International references and Hungarian examples have been chosen that enhance the inclusiveness of higher education through social innovation. The conclusion summarises our results.

\section{Theoretical Framework}

Both the functioning of higher education and the creation of products and services are characterized by a shift in power relations: persons with disability and members of other marginalized group do not appear to be active actors in the creation of knowledge necessary for progress. Curricula, research and development pertaining to persons with disability are still typically created by professionals who are not persons with disability. At the same time, co-productive solutions and methodologies for the inclusion of people with disability are increasingly available.

According to innovation-oriented approaches, higher education, citizens of local communities, the public sector, decision-makers and for-profit actors work together to develop and create the quadruple helix ecosystem (Plattner et al., 2017; Castiaux, 2016). User involvement, citizens' science, responsible science (Buchner et al., 2016) and processes based on different collaboration strategies with users are all integral, inalienable parts of the quadruple helix ecosystem (Osborn et al., 2016; Ryan, 2012; Katona \& Sándor, 2020). The so-called living labs can become important catalysts in supporting these processes (van Geenhuizen, 2016; Liedtke et al., 2012; Guzmán et al., 2013). By focusing on working together with persons with disability, we enrich the repository of social innovation practices and provide 
examples of what responsible innovation and purpose-driven innovation can mean in everyday life (Grant \& Grant, 2016; Stilgoe et al., 2013).

Several sources point out the effectiveness of involving users to be part of the team in project-based higher education innovations (Wilken et al., 2014; Chemi \& Krogh, 2017). Innovation management concepts such as user-led innovation (Bühler, 2001; Hoole \& Morgan, 2010; Munn-Giddings et al., 2009), user involvement, and user-centric innovation (Gamble et al., 2016; Selden \& MacMillan, 2006) provides a background to map the needs and ideas of those who utilise the product or service. The concepts of citizen involvement (Creighton, 2005; Ryan, 2014; Pivik, 2002; Jurkowski et al., 2002) and co-production (Cahn, 2000; Hunter \& Ritchie, 2007; Roberts et al., 2012; Brandsen et al., 2018) interpret the importance of planning, implementing and testing with stakeholders in the field of various public services and related policies.

It is increasingly common practice in the market to design products or services in such a way that the target group gets involved in the process to make it more easily adjustable to the needs of the user. Similarly, tailoring benefits and services to the needs of citizens has a raison d'être in public services, as well. There are many practices in the international arena where the products, services and benefits are the outcome of the co-production and cooperation of professionals and stakeholders. (Boyle \& Harris, 2009; Wilken et al., 2014; NOU, 2011; Voorberg et al., 2014.) In the field of disability, the user-led, citizen-led approach began to take shape (Barnes \& Mercer, 2006; Priestley et al., 2010; Concannon, 2005; CRPD, 2006) in human rights, civil rights movements and international conventions that emphasized the active participation of persons with disability in the processes. Participatory, emancipatory methods in (Critical) Disability Studies enable persons with disability to participate in both education and research (Walmsley \& Johnson, 2003; Atkinson, 2004, 2005; Schubotz, 2020). Inclusive methods used in (Critical) Disability Studies that support the empowerment of persons with disability in combination with userled procedures employed in the design of services can contribute to the implementation of disability services fitting the needs of persons with disability.

\section{From Participatory Research to Co-productive Service Development through Participatory Teaching}

\subsection{Participatory Research}

Theoretical Background of Participatory Research According to the principle "Nothing about us without us!" the (Critical) Disability Studies approach is based on the voice, decision-making and active participation of those concerned in areas that directly affect their lives. However, we cannot leave science out of this approach, even though in many cases it is persons with disability who are being studied. In the traditional canons of research, it is not customary for the researched person to take on 
the role of the researcher. This tradition is observed by inclusive research, in which it is explicitly seen as a strength and value when a person with local knowledge and lived experiences is also involved in the research (Clements et al., 1999; Mills et al., 2006; van der Riet \& Boettiger, 2009; Creswell, 2013). As Walmsley (2001, 187-188) says: „Inclusive Research is a term used to refer to a range of research approaches that have traditionally been termed participatory or emancipatory, broadly speaking research in which people with learning difficulties are involved as more than just research subjects or respondents."

The participation of the persons with disability can also contribute to a greater degree of validity, as we can adapt to the needs of this target group by actively paying attention to their lifestyles. In this way, we can formulate our research questions in a way that takes into account the needs of persons with disability during the data collection process (Mercer, 2002). We can reach a high level of understanding of social "reality" by stepping out of the world of labels. Subjective interpretations can bring us closer to understand where real people are located behind social categories and complex processes (Goodley, 1996). With inclusive research, we can get closer to breaking down the boundaries between the minority and the majority, and empower persons with disability and other marginalised people. There are two main types of this research: emancipatory research carried out entirely by members of a given marginalised group, and then participatory research, where stakeholders get involved to varying degrees in addition to non-affected researchers (Barnes, 2003; Marton \& Könczei, 2009).

What distinguishes participatory research from traditional research is that, beyond the research process, the individuals involved can influence decision-makers in professional public life and praxis. Thus, activist and advocacy elements are also characteristic (French \& Swain, 1997) of this kind of research. Inclusive projects have the explicit aim of creating an activity, service or product with the active participation of people with disability to reach a stronger impact on the lives of participants and their groups than traditional design.

In Hungary, we do not have much experience with inclusive projects, but we came across several initiatives and doctoral studies that follow this approach. (Harper, 2009; Katona, 2014; Sándor, 2018; Kunt, 2019) The research programme "From equal opportunities to Taygetus?" (Hernádi \& Kunt, 2018; Könczei, 2018), is mentioned in more detail here. In this research, the presence and experience of participatory researchers is strongly reflected in the formulation of the hypothesis and the questions related to each research component.

The hypothesis of the research was that the modern Taygetus not only exists, but can also be found by examining the hidden power structures of everyday life. The first research component consisted of 16 narrative interviews with mothers who had received a positive diagnosis of Down's syndrome at the time of their pregnancy. Their decisions regarding the continuation or terminations of their pregnancy were analysed. The second research component was about families adopting children with disability, which is a rather rare process in Hungary. Questionnaires and narrative interview techniques were used to find out the characteristics of those parents and 
families who adopt children with disability as well as the features of the adoption process. The third part of the research explored the possibilities of women and men with intellectual disability who wanted to become parents. Semi-structured lifeworld interview techniques were used. The entire research was accompanied by two main participatory researchers who were given a role in the plenary reflection space on the research. In addition, the sub-researches involved co-researchers related to the specific topics who supported the design of the research instruments.

In inclusive research, participatory and professional researchers should be given different but equal roles (Heiszer, 2017). Participation in research expands the participatory researchers' knowledge of the science and research methodology, just as, conversely, their knowledge also adds to the work (Antal, 2017). Researchers working in academia can gain insight into the life experiences of persons with disability, enriching everyone and blurring the seemingly clear boundaries of our knowledge, somewhat. (Nind, 2008; Nind \& Vinha, 2012).

To make joint work more effective, initiatives are needed to prepare participatory researchers in advance (e.g., to provide training in the basics of (Critical) Disability Studies and methodology). In the training of the so-called empowerment experts, the University College of Teacher Education in Vienna focused on mobilizing the individual resources of the participants. The goal of the training coordination team was, in line with the theory of empowerment, to primarily strengthen participants in their own abilities and encourage them to take responsibility for issues affecting their own lives. They then turned to the ideas they had e.g. in connection with the development of higher education. The practical element of the training contained, for example, situational exercises in which future empowerment counsellors with disability could express their views on disability issues. They attended, among other things, a meeting of the Committee Monitoring the Implementation of the Convention and a related project day, as well as classes in higher education. As a result of the joint work, an Inclusive Training Office was created and the participants became contributors. Graduates work on additional professional issues immediately after training and perform mentoring for newly recruited participants (Wilhelm, 2012). These knowledge elements were acquired by our participatory research colleagues during the internship, however, we believe that in the future it would be important to provide training before the research project begins. According to our plans, this type of training would also be implemented in an inclusive way, as collaboration between researchers with and without disability.

The Practice of Participatory Research Based on Experiences of the Carry on! Project Hungarian practitioners of Disability Studies have used the participatory approach in an increasing number of research projects, and at different stages of the research, the active participation of the persons with disability have been ensured by applying various techniques and the principles of participation.

The Carry on! research project is a good example of utilising the participatory method. The aim was to explore career planning pathways for students with disability in order to support further education and employment. To explore the hindering and supporting aspects, semi-structured interviews and focus group discussions were 
conducted with professionals working in schools and career guidance services as well as with young people and adults with disability (Cserti-Szauer et al., 2020).

Two co-researchers with disability who have extensive experience as users in career planning and employment services also participated in the entire process, from the research design to the data collection and analysis. The interviews were mostly recorded in pairs, where one researcher with disability and one nondisabled researcher acted as the interviewers, complementing each other as equals in both the focus group and the individual interviews. The interviews were preceded by a thorough co-preparation where the script was designed together. (Caldwell, 2014).

Interviewing in pairs has produced positive results. Apart from the initial bias of the interviewees, when the role of the researcher with disability could not be managed properly, the presence of the participative researcher added value to the overall interview situation. In some cases, the interviewees spoke even more openly due to a "peer-to-peer" atmosphere. One participatory researcher summarised the experience as follows: "I saw my presence balanced the research situation, because I felt that interviewees spoke more openly and disclosed their experiences connected to disability better. Parents not only spoke about themselves, but also about the perspectives of their children. In their answers, experts didn't hide behind the theories, they focused on practical problems and possible ways of solutions. So, the results could be more authentic.” (Sándor et al., 2019).

The techniques used in participatory research serve as additives in other areas of cooperation, such as education and service development. In addition, the research experience gained from the Carry on! project has been directly integrated into training development, providing an example not only of the interdependence of research and education, but also of the legitimation of educational materials by those who the curriculum is about.

\subsection{Participatory Teaching and Inclusive Seminars}

Theoretical Background of Participatory Teaching Much of the international literature on participatory approaches gaining ground in higher education is provided by the discourse on amplifying the voices of students from diverse backgrounds and needs. (Seale, 2010; McLeod, 2011; Brooman et al., 2014; Svendby, 2020) Educational viewpoints emerge from the experiences of emancipatory actors, particularly along different narratives of overcoming factors hindering integration into the academic environment. (French, 1998; Pritchard, 2010; Hoffmann, 2017; Flamich, 2017; Loványi, 2020) For academic persons with disability, this coping mechanism is particularly decisive and significant due to the ableist environment, and the lack of appropriate support (Williams \& Mavin, 2015; Brown \& Leigh, 2018; Mellifont et al., 2019).

Even less literature is available on participatory higher education and inclusive courses with co-teachers with different support needs. One is an inclusive project 
led by Koenig and Buchner (2009), whose participants conducted a seminar on inclusive research in which persons with intellectual disability and physical challenges studied together with the students of the course and at the same time they were also present in the process as co-teachers. Prior to the course, participants already had experience with inclusive research and self-advocacy. The content of the seminar was defined jointly by the instructors and each participatory co-teacher had the opportunity to explain a chosen topic in more detail during class. During the semester, they had to design and implement their inclusive research projects together with groups of 3-4 students. The small research groups presented their results together in a public conference at the end of the semester. It played an important role in the evaluation process of the seminar that the instructors conducted interviews with the participatory participants.

An initiative similar to that of Koenig and Buchner is reported by Klauß and his team (2008). The Heidelberg University of Education has been hosting so-called integrative seminars since 1999 for students in special education training, and persons working in workshops for persons with disability and students with intellectual disability.

The research of Katona and Sándor (2020) summarizes the experiences of inclusive seminars introduced by the Gusztáv Bárczi Faculty of Special Needs Education at the ELTE University in 2016. An inclusive seminar is defined as any higher education course in which professional instructors and participatory instructors teach together as equal partners. In this example, professional educators primarily bring their knowledge to university courses. Participatory instructors are colleagues with disability who primarily pass on their life history and life experiences in university courses. An inclusive/participatory methodology is an approach in which the method used in the project, the use of ICT tools and the involvement of participatory teachers are applied in a multi-teacher model (Katona, 2019; Katona \& Sándor, 2020).

In inclusive seminars, the partnership between colleagues is extremely important and also serves as a role model for students who often meet persons with disability for the first time during these classes. As it is suggested for students during projects to work with at least one stakeholder, this way they can also experience co-working.

Significant participation of persons with disability in classes clearly brings their experiences closer to students. It also helps to understand that persons with disability are also different, there are no communication "recipes" for everyone, as illustrated by the following example.

The Practice of Participatory Teaching Based on the Experiences
of the Inclusive Seminar 'Theory and Practice of Supported Living' Inclusive seminars are created along a variety of professional subjects. Topics such as the history of special needs education, employment, ageing and death, among others, can be included. Courses with the participation of persons with intellectual disability are of particular value, as in these co-productions, in an easy-to-understand communication environment, our co-teachers participate as equal partners both in the 
creation of knowledge content and in the knowledge transfer itself as well as its evaluation.

We launched the 'Theory and Practice of Supported Living' course aiming at developing the competencies of professionals working in supported living settings, which are gaining more and more ground in the Hungarian policy and service system and are replacing the institutional culture. After all, their role is key in empowering persons with intellectual disability, supporting their independent living, and building equal partnerships to deliver high-quality services. (Bánfalvy, 2020).

In addition to the academic knowledge base provided by professional educators from the fields of Disability Studies and social policy, we incorporated the experience of people with intellectual disability who lived in large nursing homes but moved to supported living. Our partners were Zoltán Iván, György Kalányos and their supported decision-making assistant, Ildikó Horváthné Somogyi. The aspects of family life were brought in the process by our participatory teacher András Futár (Losoncz et al., 2018).

The 20-hour-contact course was organized around five topics: the methodology of inclusive seminars, the basic principle of self-determination, empowerment and human rights, supported living as a service, and professional roles in supported living. The preparation for the lessons began with the co-development of syllabus and series of questions. Our goal was to increase the assertiveness and selfconfidence of the participatory teachers. During preparation, we used the actionoriented form of education, thus increasing the independence, and self-awareness of our participatory teachers.

Students were also receptive to new knowledge, methodology, and the involvement of participatory teachers. Here is a quote of how our participatory teachers experienced the joint work: "It was good that they listened to us with interest and were curious about us. We like to talk to students. We can also tell them new things. When we are in class, the (lot of) work we put into preparation pays off. We were very anxious during the first class, but less so later. We did not know anyone at the beginning of the course, but we also made new friends by the end. It was a difficulty in class that we did not always understand the question, or misinterpreted it. We needed help with this several times. After class, by the time we headed home, we were always very tired, but it felt good and we were proud of ourselves." (Iván et al., 2017, 151).

Co-created projects were presented to each other at the Project Festival. The projects presented theoretical issues (factors supporting and complicating selfdetermination in life, easy-to-understand communication translations) and personal stories (future plans of young people in aftercare, coming out of institutions, narratives of adults in supported living setting), as examples of teamwork models of interdisciplinary, inter-sectorial cooperation in higher education. 


\subsection{Participatory Innovation}

Theoretical Background of Participatory Innovation Involving users in various innovation processes is a valuable initiative for the development of both market products and public services (Buur \& Matthews, 2008). Product and service development processes are characterized by the need to explore user needs for their success (Ulwick, 2005). However, this is not an easy task in practice. The process is even more difficult when the users themselves are not clear about what product or service they need. All they feel is the lack of the proper products or services. Exploring the needs is also difficult because these are so-called "sticky needs" that are difficult to access (von Hippel, 1994; Sánchez-González et al., 2009). Principles of output-oriented innovation, e.g., job-based thinking emphasize that most users are not able to communicate what solution they want, but what gap they would like filled or what activity they need support with. People with disability are in a similar situation. They cannot identify personal assistance as a possible key to their selfdetermined life, rather they experience difficulties if this service is unavailable.

In many cases, during development attempts are made to gather information from users through some form of quantitative or qualitative research, such as market research or focus group interviews. However, the democratization of innovation is characterized by the emergence of users at an earlier stage and with a higher level of participation, for example due to the lead-user method or the co-creation approach (von Hippel, 2005; Chemi \& Krogh, 2017). Monitoring the activities of lead-users (Brem et al., 2018), Participatory Design or Design Anthropology (Buur \& Matthews, 2008) served the same goal but with a different focus: of getting to better understand the perspective and needs of the product and service provide the best possible solutions for users.

Participatory innovation has a dual purpose. On the one hand, it is gathering knowledge about users that inspires product and service development, and on the other, implementing these developments for business purposes (Buur \& Matthews, 2008).

Buur and Matthews (2008) identify five activities that characterize participatory innovation: (a) field study, where ethnographic research helps to get to know the people whose voices might be strengthened; (b) sense-making, where the observed practices and needs are analysed with the involvement of industrial actors and users; (c) co-ideation, when these actors think about the business opportunity inherent in product and service development ideas; (d) business modelling, when business models behind product and service development are created with the involvement of industry and users; (e) co-design, when a specific product prototype or service pilot is implemented.

In the area of public policy and service development, co-production has become an extremely popular approach in the last decade. As an example, there is a Norwegian document Innovation in the Care Services (NOU, 2011), that emphasises home care services designed in partnership with families. We also draw attention to Northern Ireland's Disability Strategy, which was developed by Disability Action, 
an advocacy umbrella organisation, and the Department of Health, Social Services and Public Safety. In FREDA project, Roberts et al. (2012) worked with people with intellectual disability to create human rights training materials and curricula. Purcel et al. (2019) mentions the Australian National Disability Insurance Scheme and the research \& development methods that might strengthen disability-inclusive and user-led opportunities. To summarize briefly the essence of the idea, users of various public services (mainly education, child protection, social and health services), their families and neighbours, and the service provider organizations work in partnership to design, manage, implement and evaluate given service (Bonfils \& Askheim, 2014; Brandsen et al., 2018).

The concept is interpreted in the context of the new social economy model, which by exiting the traditional production-consumption process, puts the emphasis on innovation and social networks (Murray, 2009). Co-production is also closely related to the concept of empowerment, as it aims to give users power and responsibility to control their own lives. Recipients of services are competent citizens who have the right to improve the quality and accessibility of various public services with their own knowledge and resources (Bonfils \& Askheim, 2014).

This idea is also in contrast with the traditional hierarchical specialist model of welfare services, as well as the market approach, where users appear exclusively as consumers. Co-production, by designing and creating services with users, provides an extremely diverse repertoire-with a number of local and individual adaptations (Bonfils \& Askheim, 2014).

\section{The Practice of Participatory Innovation Based on the Freekey Project for the Development of Personal Assistance Services The Disability/Studies/ and Social/Innovation Lab was created in this participatory innovation and co-productive approach with the goal of assisting disabled and nondisabled Lab members with research-based product and service development along the real needs of users.}

The DSSI Lab operates in an academic environment, thereby strengthening the potential of higher education to contribute to social change in the field of disability. We also aim to support the quadruple helix ecosystem, where the academic, policy, industrial/business and civil sectors work together in a variety of areas to improve the quality of life of people with disability and figure out:

- how to link academic and disability movement activities and transform them into social innovations,

- how to how to extend participatory teaching and research and social innovations stemming from them beyond the disability field,

- how to strengthen personal assistance as a research and development and innovation activity for sustainable societies.

As a project of the DSSI Lab, Freekey came about as a group of persons with and without disability. The founders of this bottom-up initiative are persons with disability and professional researchers. 
During the joint work, it has become clear that the possibility of equal co-operation as colleagues is primarily influenced by environmental factors, such as equal access, accessible transportation and the presence or absence of personal assistance services. In Hungary, the user-managed 24/7 personal assistance service for persons with disability is not legally guaranteed, and models financed from individual resources are extremely difficult to maintain. A common strategy combining life experiences and learned knowledge has begun to develop with the goal of launching a co-productive, participatory service.

A direct antecedent of this development is Shakespeare et al.'s (2018) presentation the annual Disability Studies Conference in Budapest, which examined narratives related to personal assistance in England. This experience triggered the need to organize a joint action in the participants of the conference. This was followed by two workshops that gathered the opinions and experiences of stakeholders (Csángó \& Sándor, 2019; Sándor et al., 2018). One of the biggest challenges during the conversations was that persons with disability themselves should be getting information about the service empowering them to fight for their own rights. Otherwise, fear and even resistance may surround the intention to develop at a later stage, as was the case with the introduction of other community-based services, such as supported living.

In 2019, eight further members were involved and the organization of a community began in which users and researchers would be equally represented in order to achieve balance of power relations. Strong emphasis is placed on developing the co-decision making process and defining roles. The task of researchers is primarily to create the conditions for activities and provide reflection on them. Users, in turn, gain control over the definition of topics, the communication of common goals, and appear as active citizens in the community organization process. The bottom-up initiative is reinforced from the outset by the fact that educational and research results can be immediately incorporated into the work of activism and community organizing and vice versa: experiences of the project practices have a strong impact on university education and research.

The first joint project was an outreach and community building series. Based on the experiences of the workshops, the project provided knowledge in an easy-tounderstand way, through films, ${ }^{1}$ about how the service enables self-determination. The advantage of co-production and co-creation is that there is constant feedback about the service you want to improve from those who are targeted by the development. In order for the opinions to be incorporated effectively, it is worth slowing down the rhythm and schedule of the projects in order for each team member to play a significant role in it. It is good practice to recruit people with an interest in personal assistance and experience in self-advocacy and public performance. It is not they who fit the tasks, but during the process tasks and roles that best fit their skills are created. Experience shows that, for this reason, it is essential to examine and analyse

\footnotetext{
${ }^{1}$ https://youtu.be/wAbnBjY2zx4, https://www.facebook.com/freekey8/videos/226051768840782/, https://www.facebook.com/103761497962643/videos/280246450082174
} 
individual resources, areas for development, ambitions and needs at the individual and group levels.

The challenge in co-development is that supporting participants' empowerment processes is extremely time consuming. It is particularly difficult to involve people in a complex, empowering operation who have been forced into a passive role until then by their socialization. At the same time, professionals may find it difficult to share power, to involve persons with disability in innovation activities and to empower them. Since it is true here, as well, that not everybody has to do the same thing for equal work to take place, the definition of tasks, roles and competencies is key. In a democratic group, managing these things flexibly can benefit the work, but at the same time, it can cause tension and frustration when someone feels they are expected to take part in tasks that are difficult, inaccessible, or just too simple and not challenging enough for them. Honest communication has contributed to the fact that after a year of working together, not only good results in the development of the personal assistance service were achieved, but also the organizational operation became clearer and smoother.

\section{Conclusions and Plans for the Future}

As discussed in the chapter more than one billion people in the world live with disability. (Critical) Disability studies focus on their lives as persons with disability are often unable to enjoy political, economic and social rights and are excluded from their communities. Reducing their oppression and marginalisation, supporting their empowerment and their inclusion in local communities is a priority that should be on the agenda of higher education stakeholders.

In the practice described by the chapter persons with disability might be involved in the creation of higher education knowledge content that is about or affects their lives. Their voices must be heard by those involved in higher education. "Nothing about us without us!" principle needs to be mainstreamed in research, teaching and innovation. Mainstreaming (Critical) Disability Studies and human rights perspective is also an efficiency issue. User involvement in project-based higher education innovations leads to social impact and strengthens inclusive communities, as described by several sources.

The inclusive higher education methods presented in this chapter might promote the activation and involvement of people with disability in research, education and innovation, which opens up new areas of social participation. They also support academics to become more diverse and inclusive.

Persons with disability become active subjects of research instead of being objects in emancipatory and participatory research. As researchers, they raise issues and questions that are significant for them. This increases the credibility and relevance of the research. Non-participatory researchers can gain a deeper insight into the life situations and experiences of people with disability, which will make their knowledge more diverse and manifold. The presented international and 
Hungarian research focuses on several areas of disability issues, giving examples of ways to benefit from the added value of participative work.

We experienced that participatory research results can be integrated into higher education portfolios in a number of ways. One track is through participatory teaching, where persons with disability and nondisabled people work together as partners but in different roles. Participatory teachers bring their lived experiences and life stories to the classroom, while non-participatory educators add their academic background. Course topics provide opportunities for a range of teachers to share their experiences related to the disability field: mutual rethinking of mainstream and disability services, empowerment and supported decision-making are among them.

Participatory higher education practices related to the inclusion of people with disability are known from Oliver Koenig, Tobias Buchner and Theo Klauß et al., mainly in higher education institutions of Germany and Austria. The Hungarian practice of involving participative teachers with different support needs develops these traditions. Inclusive seminars enrich Gusztáv Bárczi Faculty of Special Education, Eötvös Loránd University for at least two reasons: the long-term involvement of people with intellectual disability and the pedagogical methodology. By involving people with intellectual disability, the empowerment of one of the most vulnerable groups is enhanced. Co-productive work with them also makes academic communication more accessible through an easy-to-understand method. The pedagogical methodology of the inclusive seminars combines elements of project-based learning, info-communication tools and the multi-teacher model with participatory characteristics.

Participatory innovation provides opportunity to involve users in the design, implementation and piloting processes for both market products and public services. It makes available consumer feedback that is valuable for producers, developers, policy makers and democratises the innovation process. The personal assistance service development presented in the chapter provides an example of this colourful and multifaceted process by describing the co-productive elements.

However, co-working brings a number of challenges. The pace of innovation is slowing down to have enough time for empowering people with different support needs, to make their voices heard. Accessibility of the built and communication environment must be ensured, otherwise collaboration will not work. However, it is worth overcoming the challenges because the inclusion of users with disability results in a richer quadruple helix ecosystem.

Our practice confirmed that the disability experience is a valuable resource not just in research, but in teaching (Critical) Disability Studies as well. We are convinced that the method the chapter described might become a valuable tool in establishing more inclusive communities and the participatory approach will contribute to the development of user-friendly products and services.

The future of research, education and innovation together with people with disabilities can also move towards intersectional multiplication. Participative approach focuses on the inclusion of marginalised people, not only in relation to disability, but also on other intersectional groups, such as women with disability or 
ethnic minorities with disability, or even women from ethnic minorities. This complex direction goes beyond the (Critical) Disability Studies perspective, but can enrich the innovation ecosystem with inclusive solutions.

\section{References}

\section{Journal Articles}

Antal, Z. S. (2017). Kölcsönös tisztelet és nyitottság. Participatív beszámoló egy fogyatékosságtudományi kutatásról [Mutual Respect and Openness]. Új Pedagógiai Szemle, 5-6, 77-84.

Atkinson, D. (2004). Research and empowerment: Involving people with learning difficulties in oral and life history research. Disability \& Society, 19(7), 691-702.

Atkinson, D. (2005). Research as social work: Participatory research in learning disability. British Journal of Social Work, 35(4), 425-434.

Bánfalvy, C. S.. (2020). The social integration of disabled persons. The Contribution of Education and Employment Fogyatékosság és Társadalom, Special Issue, 10-28. https://doi.org/10.31287/ FT.en.2020.2.3.

Barnes, C. (2003). What a difference a decade makes: Reflections on doing 'emancipatory' disability research. Disability \& Society, 18(1), 3-17.

Bonfils, I. S., \& Askheim, O. P. (2014). Empowerment and personal assistance-resistance, consumer choice, partnership or discipline? Scandinavian Journal of Disability Research, 16(S1), 62-78. https://doi.org/10.1080/15017419.2014.895414

Brem, A., Bilgram, V., \& Gutstein, A. (2018). Involving Lead users in innovation: A structured summary of research on the Lead user method. International Journal of Innovation and Technology Management, 15(3). https://doi.org/10.1142/S0219877018500220

Brooman, S., Darwent, S., \& Pimor, A. (2014). The student voice in higher education curriculum design: Is there value in listening? Innovations in Education and Teaching International, 52(6), 663-674. https://doi.org/10.1080/14703297.2014.910128

Brown, N., \& Leigh, J. (2018). Ableism in academia: Where are the disabled and ill academics? Disability \& Society, 33(6), 985-989. https://doi.org/10.1080/09687599.2018.1455627

Buur, J., \& Matthews, B. (2008). Participatory innovation. International Journal of Innovation Management, 12(03), 255-273. https://doi.org/10.1142/S1363919608001996

Bühler, C. (2001). Empowered participation of users with disabilities in R\&D projects. International Journal of Human-Computer Studies, 55(4), 645-659. https://doi.org/10.1006/ijhc.2001. 0489

Caldwell, K. (2014). Dyadic interviewing: A technique valuing interdependence in interviews with individuals with intellectual disabilities. Qualitative Research, 14(4), 488-507. https://doi.org/ $10.1177 / 1468794113490718$

Clements, J., Rapley, M., \& Cummins, R. A. (1999). On, to, for with-vulnerable people and the practices of the research community. Behavioural and Cognitive Psychotherapy, 27, 103-115. https://doi.org/10.1017/S1352465899272013

Cserti-Szauer C. S., Bányai B., Katona V., \& Sándor A. (2020). Narratives of struggle lifelong guidance and future planning alternatives for people with disabilities in hungary. Fogyatékosság és Társadalom, Special Issue, 59-75. https://doi.org/10.31287/FT.en.2020.2.6.

French, S., \& Swain, J. (1997). Changing disability research: Participating and emancipatory research with disabled people. Physiotherapy, 83(1), 26-32. https://doi.org/10.1016/S00319406(05)66107-X 
Gamble, J. R., Brennan, M., \& McAdam, R. (2016). A contemporary and systematic literature review of user-centric innovation: A consumer perspective international. Journal of Innovation Management, 20(1), 1-45. https://doi.org/10.1142/S1363919616500110

Goodley, D. (1996). Tales of hidden lives: A critical examination of life history research with people who have learning difficulties. Disability \& Society, 11(3), 333-348. https://doi.org/10. $1080 / 09687599627642$

Grant, G., \& Grant, A. (2016). Why innovation must be purpose-driven: Lessons from the Australian outback. Modern Business, 24-25.

Guzmán, J. G., del Cario, A. F., Colomo-Palacios, R., \& de Diego, M. V. (2013). Living labs for user-driven innovation: A process reference model. Research-Technology Management, 56(3), 29-39. https://doi.org/10.5437/08956308X5603087

Hernádi, I., \& Kunt, Z. S. (2018). 'Prenatal screaming' decision-making following a prenatal diagnosis of down syndrome. Hungarian Journal of Disability Studies \& Special Education., Special Issue, 26-42. https://doi.org/10.31287/FT.en.2018.1.4

Hoole, L., \& Morgan, S. (2010). It's only right that we get involved: Service-user perspectives on involvement in learning disability services. British Journal of Learning Disabilities, 39(1), 5-10. https://doi.org/10.1111/j.1468-3156.2009.00563.x

Jurkowski, E., Jovanovic, B., \& Rowitz, L. (2002). Leadership/citizen participation: Perceived impact of advocacy activities by people with physical disabilities on access to health care, attendant care and social services. Journal of Health \& Social Policy, 14(4), 49-61. https://doi. org/10.1300/J045v14n04_04

Könczei, G. (2018). We already know how the 'sunny side' works, let us now try to understand the effects of the 'dark side' on the lives of people with disabilities (summary of the research plan). Hungarian Journal of Disability Studies \& Special Education, Special Issue, 2018, 7-16. https://doi.org/10.31287/FT.en.2018.1.2

Liedtke, C., et al. (2012). LIVING LAB: User-driven innovation for sustainability. International Journal of Sustainability in Higher Education, 13(2), 106-118. https://doi.org/10.1108/ 14676371211211809

Losoncz, M., Bogdán, B., Cserti-Szauer, C. S., Katona, V., \& Sándor, A. (2018). 'The process is far more complicated than I thought'. Experiences of an innovative and inclusive curriculum development in higher education. Hungarian Journal of Disability Studies \& Special Education, Special Issue, 2018, 64-71. https://doi.org/10.31287/FT.en.2018.1.7

Marton, K., \& Könczei, G. Y. (2009). Új kutatási irányzatok a fogyatékosságtudományban. Fogyatékosság és Társadalom, 1, 5-12.

McLeod, J. (2011). Student voice and the politics of listening in higher education. Critical Studies in Education, 52(2), 179-189. https://doi.org/10.1080/17508487.2011.572830

Mellifont, D., Smith-Merry, J., Dickinson, H., Llewellyn, G., Clifton, S., Ragen, J., Raffaele, M., \& Williamson, P. (2019). The ableism elephant in the academy: A study examining academia as informed by Australian scholars with lived experience. Disability \& Society, 34(7-8), 1180-1199. https://doi.org/10.1080/09687599.2019.1602510

Mills, J., Bonner, A., \& Francis, K. (2006). The development of constructivist grounded theory. International Journal of Qualitative Methods, 5(1), 25-35. https://doi.org/10.1177/ 160940690600500103

Munn-Giddings, C., et al. (2009). The innovative role of user-led organisations. A life in the day, 13 (3), 14-20. https://doi.org/10.1108/13666282200900026

Osborn, S. P., Radnor, Z., \& Strokosch, K. (2016). Co-production and the co-creation of value in public services. A suitable case for treatment? Public Management Review, 18(5), 639-653. https://doi.org/10.1080/14719037.2015.1111927

Priestley, M., Waddington, L., \& Bessozi, C. (2010). New priorities for disability research in Europe: Towards a user-led agenda. ALTER, European Journal of Disability Research, 4, 239-225. https://doi.org/10.1016/j.alter.2010.07.001

Pritchard, G. (2010). Disabled people as culturally relevant teachers. Journal of Social Inclusion, 1 (1), 43-51. https://doi.org/10.36251/josi.4 
Purcel, C., Fisher, K. R., Robinson, S., Meltzer, A., \& Bevan, N. (2019). Co-production in peer support group research with disabled people. Area, 51(3), 405-414.

Roberts, A., Greenhill, B., \& Talbot, A. (2012). 'Standing up for my human rights': A group's journey beyond consultation towards co-production. British Journal of Learning Disabilities, 40(4), 292-301. https://doi.org/10.1111/j.1468-3156.2011.00711.x

Ryan, B. (2012). Co-production: Option or obligation? Australian Journal of Public Administration, 71(3), 314-324. https://doi.org/10.1111/j.1467-8500.2012.00780.x

Ryan, R. (2014). Innovative citizen involvement for creating public value in local government. The Journal of African \& Asian Local Government Studies, 35-49.

Sánchez-González, G., González-Álvarez, N., \& Nieto, M. (2009). Sticky information and heterogeneous needs as determining factors of R\&D cooperation with customers. Research Policy, 38 (10), 1590-1603. https://doi.org/10.1016/j.respol.2009.09.012

Seale, J. (2010). Doing student voice work in higher education: An exploration of the value of participatory methods. British Educational Research Journal, 36(6), 995-1015. https://doi.org/ 10.1080/01411920903342038

Selden, L., \& MacMillan, I. C. (2006). Manage customer centric innovation-systematically. Harvard Business Review.

Shakespeare, T., Stöckl, A., \& Porter, T. (2018). Metaphors to work by: The meaning of personal assistance in England. International Journal of Care and Caring, 2(2), 165-179. https://doi.org/ $10.1332 / 239788218 X 15187915600658$

Stilgoe, J., Owen, R., \& Macnaghten, P. (2013). Developing a framework for responsible innovation. Research Policy, 42(9), 1568-1580. https://doi.org/10.1016/j.respol.2013.05.008

Svendby, R. (2020). Lecturers' teaching experiences with invisibly disabled students in higher education: Connecting and aiming at inclusion. Scandinavian Journal of Disability Research, 22(1), 275-284. https://doi.org/10.16993/sjdr.712

van der Riet, M., \& Boettiger, M. (2009). Shifting research dynamics: Addressing power and maximising participation through participatory research techniques in participatory research. South Africa Journal of Psychology, 39(1), 1-18. https://doi.org/10.1177/ 008124630903900101

van Geenhuizen, M. (2016). Living labs as boundary-spanners between triple helix actors. Journal of Contemporary Eastern Asia, 15(1), 78-97. https://doi.org/10.17477/jcea.2016.15.1.078

von Hippel, E. (1994). Sticky information and the locus of problem-solving: Implications for innovation. Management Science, 40(4), 429-439. https://doi.org/10.1287/mnsc.40.4.429

von Hippel, E. (2005). Democratizing innovation. The evolving phenomenon of user innovation. Journal für Betriebswirtschaft, 55(1), 63-78. https://doi.org/10.1007/s11301-004-0002-8

Voorberg, W. H., Bekkers, V. J. J. M., \& Tummers, L. G. (2014). A systematic review of co-creation and co-production. Embarking on the social innovation journey. Public Management Review, 17(9), 1333-1357. https://doi.org/10.1080/14719037.2014.930505

Williams, J., \& Mavin, S. (2015). Impairment effects as a career boundary: A case study of disabled academics. Studies in Higher Education, 40(1), 123-141. https://doi.org/10.1080/03075079. 2013.818637

Wilken, J. P., Medar, M., Bugarszki, Z., \& Leenders, F. (2014). Community support and participation among persons with disabilities. A study in three European countries. Journal of Social Intervention: Theory and Practice, 23(3), 44-59.

Walmsley, J. (2001). Normalisation, emancipatory research and inclusive research in learning disability. Disability \& Society, 16(2), 187-205. https://doi.org/10.1080/09687590120035807 


\section{Book and Book Chapters}

Barnes, C., \& Mercer, G. (2006). Independent futures. Creating user-led disability Services in a Disabling Society. The Policy Press. https://doi.org/10.2307/j.ctt9qgmh3

Brandsen, T., Steen, T., \& Verschuere, B. (2018). Co-production and co-creation engaging citizens in public services. Routledge. https://doi.org/10.4324/9781315204956

Buchner, T., Koenig, O., \& Schuppener, S. (2016). Inklusive Forschung. Gemeinsamkeit mit Menschen mit Lernschwierigkeiten forschen. Klinkhardt Verlag.

Cahn, E. S. (2000). No more throw-away people. The co-production imperative. Essential Books.

Castiaux, A. (2016). From the triple to the quadruple helix: Living labs as "in vivo" research entities (pp. 180-183). In C. Ghymers \& P. Leiva (Eds.), Construyendo El Espacio ComÚn de Educación Superior, Ciencia, Tecnología e Innovación para la Asociación Estratégica Birregional. Bruselas.

Chemi, T., \& Krogh, L. (2017). Co-creation in higher education students and educators preparing creatively and collaboratively to the challenge of the future. Sense Publishers. https://doi.org/ 10.1007/978-94-6351-119-3

Concannon, L. (2005). Planning for life. Involving adults with learning disabilities in service planning. Routledge. https://doi.org/10.4324/9780203017845

Creighton, J. L. (2005). The public participation handbook: Making better decisions through citizen involvement. Jossey-Bass.

Creswell, J. W. (2013). Qualitative inquiry \& research design (3rd ed.). SAGE Publishing.

French, S. (1998). Surviving the institution: Working as a visually disabled lecturer in higher education (pp. 31-41). In D. Malina \& S. Maslin-Prothero (Eds.), Surviving the academy. Feminist perspectives. Falmer Press. https://doi.org/10.4324/9780203210130_chapter_3

Goodley, D. (2017). Disability studies: An interdisciplinary introduction. Sage Publication.

Hunter, S., \& Ritchie, P. (2007). Co-production and personalisation in social care: Changing relationships in the provision of social care. Jessica Kingsley.

Iván, Z., Kalányos, GY., Horváthné Somogyi, I. \& Cserti-Szauer, CS. (2017). A Támogatott lakhatás elmélete és gyakorlata-Egy inkluzív felsóoktatási kurzus tapasztalatairól [theory and practice of supported living. Experiences of a higher education course] (pp. 147-155). In Katona V., Cserti-Szauer CS., Sándor A. (szerk.). Együtt oktatunk és kutatunk! Inkluzív megközelítés a felsôoktatásban. [we teach and make research together! The inclusive approach in higher education.] : ELTE BGGYK: Eötvös Kiadó.

Katona, V. (2019). In C. S. Cserti-Szauer \& A. Sándor (Eds.), Együtt oktatunk és kutatunk! Inkluzív megközelités a felsóoktatásban. [we teach and make research together! The inclusive approach in higher education.]. ELTE BGGYK, Eötvös Kiadó.

Klauß, T., Kunze, M., Plauth, C., \& Schüfer, M. (2008). Die Heidelberger integrativen Hochschulseminare. In G. Heß, G. Kagemann-Harnack, \& W. Schlummer (Eds.), Wir wollenwir lernen-wir können! Erwachsenenbildung, Inklusion, Empowerment (pp. 256-263). Bundesvereinigung Lebenshilfe e. V.

Koenig, O., \& Buchner, T. (2009). Inklusion in Forschung und Lehre am Beispiel des Seminars "Partizipative Forschungsmethoden mit Menschen mit Lernschwierigkeiten" an der Universität Wien. In J. Jerg, S. Thalheim, \& K. Merz-Atalik (Eds.), Perspektiven auf Entgrenzung. Dokumentation der 23. Jahrestagung der IntegrationsforscherInnen der deutschsprachigen Länder (pp. 123-131). Klinkhardt.

Könczei, G., \& Sándor, A. (2019). Spirituality and disability. (pp 159-166). In L. Zsolnai \& B. Flanagan (Eds.), The Routledge international handbook of spirituality in society and the professions. Routledge, Taylor \& Francis Group. https://doi.org/10.4324/9781315445489

Mercer, G. (2002). Emancipatory disability research. In C. Barnes, M. Oliver, \& L. Barton (Eds.), Disability studies today (pp. 228-249). Polity Press.

Pivik, J. R. (2002). Practical strategies for facilitating meaningful citizen involvement in health planning. Discussion Paper No. 23. Commission on the Future of Health Care in Canada. 
Plattner, H., Meinel, C., \& Leifer, L. (2017). Design thinking research building innovation eco-systems. Springer.

Schubotz, D. (2020). Participatory research. SAGE Publishing.

Ulwick, A. W. (2005). What customers want. Using outcome-Driven Innovation to Create Breakthrough Products and Services.

Wilhelm, M. (2012). Implementierung und Evaluation eines Ausbildungslehrganges der PH Wien für Menschen mit Beeinträchtigungen-"EmpowermentBerater/in für inklusive Schulentwicklung”(pp. 11-26). In C. Fridrich, H. Grössing, \& M. Heissenberger (Eds.), Forschungsperspektiven 4. Wien.

Walmsley, J., \& Johnson, K. (2003). Inclusive research with people with learning disabilities. Jessica Kingsley Publishers.

\section{On-Line Documents}

Boyle, D. \& Harris, M. 2009. The challenge of co-production. How equal partnerships between professionals and the public are crucial to improving public services. Discussion paper. NEF, The Lab, NESTA. Accessed Jan 31, 2021, from https://neweconomics.org/uploads/files/ 312ac8ce93a00d5973_3im6i6t0e.pdf

Convention on the Rights of Persons with Disabilities. (2006). United Nations. Accessed Jan 31, 2021, from https://www.un.org/development/desa/disabilities/convention-on-the-rights-ofpersons-with-disabilities.html

Csángó, D., \& Sándor, A. (2019). Working with Allies for Independent Living in Hungary. Accessed Jan 31, 2021, from https://enil.eu/news/working-with-allies-for-independent-livingin-hungary/

Flamich, M. M. (2017). Competencies in inclusive teacher education-Blind and Low Vision Professional Musicians', Music Students' and Their Teachers' Beliefs on Inclusion, Teacher Competencies and Their Development. Summary of Doctoral Dissertation. Budapest: Eötvös Loránd University. Accessed Jan 31, 2021, from https://ppk.elte.hu/file/Flamich_Maria_ Magdolna_Tezisfuzet_angol.pdf

Harper, K. (2009). Across the bridge: Using PhotoVoice to study environment and health in a Romani community. Anthropology Department Faculty Publication Series. University of Massachusetts-Amherst, The Sajó River Association for Environment and Community Development, Hungary. Accessed Jan 31, 2021, from https://core.ac.uk/download/pdf/13599867.pdf

Heiszer, K. (2017). Participatory research involving individuals with intellectual disabilities: The adaptation of the play decide method. Summary of doctoral dissertation. Budapest: Eötvös Loránd Tudományegyetem. Accessed May 5, 2021, from https://edit.elte.hu/xmlui/bitstream/ handle/10831/40387/Heiszer_Katalin_tezisfuzet_angol.pdf?sequence $=3 \& \% 3 \mathrm{Bis}$ Allowed $=\mathrm{y} \&$ fbclid=IwAR3Oy8pBR9FVVGLYx2AWLzHz0Thexo_iKL0NOvDE100Roixa5cTNcoLB9k4

Hoffmann, M. R. (2017). Preparing teachers for inclusive education-Relevance and perspectives of cultural disability studies in teacher education. Summary of doctoral dissertation. Budapest: Eötvös Loránd University. Accessed Jan 31, 2021, from https://ppk.elte.hu/file/Hoffmann_M_ ria_Rita_T_zisek_angol_2017-06-29.pdf

Katona, V. (2014). The social aspects of the transition to adulthood of people with physical disabilities the possibility of their acquiring resilience in the course of their lives. Summary of doctoral dissertation. Budapest: Eötvös Loránd University. Accessed Jan 31, 2021, from https:// ppk.elte.hu/file/katona_vanda_tf_a.pdf

Katona V. \& Sándor A. (2020). Az inkluzív felsóoktatási módszertan adaptációs lehetôségei egy metakutatás alapján. Záróbeszámoló. [Adaptation Opportunities of Inclusive Higher Education Method. The case of a meta research] Accessed Jan 31, 2021, from https://edit.elte.hu/xmlui/ bitstream/handle/10831/49697/Katona_S\%C3\%A1ndor_NKP\%20kutat\%C3\%A1s\%20z\% C3\%A1r\%C3\%B3besz\%C3\%A1mol\%C3\%B3_2020_A.pdf?sequence=2\&isAllowed=y 
Kunt, Z. S. (2019). CONNECTIONS personal assistance and cooperation reflected at the encounter of disability studies and cultural anthropology. : Eötvös Loránd University. Accessed Jan 31, 2021, from https://ppk.elte.hu/dstore/document/250/Kunt\%20Zsuzsanna_angol\%20t\% C3\%A9zisf\%C3\%BCzet_v\%C3\%A9gleges.pdf

Loványi, E. (2020). The role of service dogs in social integration-The results of an emancipatory research. Summary of doctoral dissertation. Eötvös Loránd University. https://ppk.elte.hu/ dstore/document/453/Lovanyi_Eszter_tezisfuzet_angol_VEGLEGES_20200228.pdf

Murray, R. (2009). Danger and opportunity. Crisis and the new social economy. NEF, The Lab, NESTA. Accessed Jan 31, 2021, from https://media.nesta.org.uk/documents/danger_and_ opportunity.pdf

Nind, M. (2008). Conducting qualitative research with people with learning, communication and other disabilities: Methodological challenges. Project report. National Centre for Research Methods. Accessed Jan 31, 2021, from http://eprints.ncrm.ac.uk/491/1/ MethodsReviewPaperNCRM-012.pdf

Nind, M. \& Vinha, H. (2012). Doing research inclusively, doing research well? Report of the study: Quality and capacity in inclusive research with people with learning disabilities. Southampton: University of Southampton. Accessed Jan 31, 2021, from http://www.southampton.ac. https:// cdn.southampton.ac.uk/assets/imported/transforms/content-block/UsefulDownloads_Down load/97706C004C4F4E68A8B54DB90EE0977D/full_report_doing_research.pdf

NOU (2011). Innovation in the Care Services. Report by the Committee appointed on 26. June 2009 Submitted to the Ministry Health and Care Services on 16 June 2011. Accessed Jan 31, 2021, from https://www.regjeringen.no/contentassets/5fd24706b4474177bec0938582e3964a/en-gb/ pdfs/nou201120110011000en_pdfs.pdf

Sándor, A. (2018). Self-determination opportunities of persons with high support needs. Summary of doctoral dissertation. Eötvös Loránd University. Accessed Jan 31, 2021, from http://ppk.elte. hu/file/sandor_aniko_tezisfuzet_angol.pdf

Sándor, A., Csángó, D., Tóth, K., Antal, Zs., \& Kunt, Zs. (2018). Let's Talk About Personal Assistance. Accessed Jan 31, 2021, from https://enil.eu/news/lets-talk-about-personala s s i stance/? f b c lid =I w A R 38 - E C V E w v c T C Gn 1 Z A j X c Y mWBkfFiQQ9zAEtCoSnQfxWxtPREDXLLua-o

Sándor, A., Katona, V., Tóth, K. \& Csángó, D. (2019). Lifelong guidance alternatives for young disabled persons in Hungary. In Histories, Practices and Policies of Disability: International, Comparative and Transdisciplinary Perspectives - 8th Annual Conference of Alter, European Society for Disability Research. 111, Accessed May 5, 2021, from https://alterconf2019. sciencesconf.org/

WHO \& The World Bank. (2011). World report on disability. Geneva: World Health Organisation. Accessed May 5, 2021, from https://www.who.int/teams/noncommunicable-diseases/sensoryfunctions-disability-and-rehabilitation/world-report-on-disability

Csilla Cserti-Szauer, PhD Student is a Special Education Teacher and an economist at Eötvös Loránd University, Bárczi Gusztáv Faculty of Special Needs Education. She has thorough experience in developing public services for adults with disabilities related to employment and independent living. As a founding member of Disability/ Studies/ and Social/Innovation Lab she generates higher education research \& development programmes that enhance collaboration between academia and the surrounding communities. Her $\mathrm{PhD}$ research is on the topic of career guidance empowering people with intellectual disabilities.

Anikó Sándor graduated as a special needs teacher and therapist and as an economist. She works as Vice-Director and Associate Professor at the Institute for Disability and Social Participation at Eötvös Loránd University Bárczi Gusztáv Faculty of Special Needs Education. Her doctoral dissertation examined the self-determination possibilities and challenges of adults with high support needs. She is a founding member of Freekey and the Disability/Studies/and Social/Innovation Lab. 
She is the leader of the Disability Studies Doctoral Workshop and a mentor of the Social Entrepreneurship Incubation Program. The field of her research and teaching activities are: Disability Studies, participatory research and teaching, supported decision making, community based support services, Personal Assistance, high support needs, end of life care.

Vanda Katona, $\mathrm{PhD}$ is sociologist and works as Associate Professor at the Institute for General Theory of Special Needs Education at Eötvös Loránd University Bárczi Gusztáv Faculty of Special Needs Education. She wrote her PhD dissertation about the Independent Living of persons with physical disabilities, focused on their resilience, based on a participatory approach. She has conducted several participatory research projects and teaches students of special needs education on bachelor and master level. The field of her research and teaching activities are: Disability Studies, transition to adulthood and parenting of persons with disabilities, social history of disability, social inclusion, deinstitutionalization, inclusive research and inclusive methods in higher education. She is the leader of the Disability Studies Doctoral Workshop and a core member of Freekey and the Disability/Studies/and Social/Innovation Lab.

György Könczei, PhD is economist and Professor of Disability Studies at Eötvös Loránd University, Bárczi Gusztáv Faculty of Special Needs Education, he teaches at BA, MA and doctoral level. He was the editor of the Hungarian Act No. 1998/XXVI. for the rights and equal opportunities of persons with disabilities in 1997/98. He was the founder (and for several earlier years) chief editor of the Hungarian-English language periodical on Disability Studies and special education; founder of the Disability Studies Doctoral Workshop and director of the Institute for Disability and Social Participation at the Faculty he works for. Earlier he served as a member of the Committee on the Rights of Persons with Disabilities of the United Nations' CRPD.

Open Access This chapter is licensed under the terms of the Creative Commons Attribution 4.0 International License (http://creativecommons.org/licenses/by/4.0/), which permits use, sharing, adaptation, distribution and reproduction in any medium or format, as long as you give appropriate credit to the original author(s) and the source, provide a link to the Creative Commons license and indicate if changes were made.

The images or other third party material in this chapter are included in the chapter's Creative Commons license, unless indicated otherwise in a credit line to the material. If material is not included in the chapter's Creative Commons license and your intended use is not permitted by statutory regulation or exceeds the permitted use, you will need to obtain permission directly from the copyright holder.

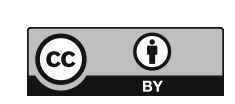

